\title{
Ethnobotanical Analysis of Cultivated and Indigenous Plants in Duhok Province in Iraq
}

\author{
Falah Saleh Mohammed ${ }^{1}$, Hasan Akgül ${ }^{2 *}$
}

${ }^{1}$ Department of Biology, Faculty of Science and Literature, Gaziantep University, 27310 Gaziantep, Turkey ${ }^{2}$ Department of Biology, Faculty of Science, Akdeniz. University, 07058 Antalya, Turkey A R T I C LE IN F O

Research Article

Received 01 May 2018

Accepted 10 June 2018

Keywords:

Medicinal plants

Alternative medicine

Ethnobotanics

Duhok

Iraq
A B S T R A C T

The present study was conducted in the province of Duhok (Northern Iraq) between 2011-2012. The study attempted to determine the use of certain indigenous and cultivated plants in Duhok province in alternative medicine and place of these plants in systematics. Thus, 49 taxa in 27 genera and 46 species were identified. Two taxa belonged to Coniferophyta, one belonged to Pteridophyta and 46 belonged to Magnoliophyta dividions. It was determined that the family with the most numerous taxa in the region was Rosaceae with 5 taxa, followed by the Fabaceae and Lamiaceae family with 4 taxa and Apiaceae, Asteraceae, Cucurbitaceae and Poaceae family with 3 taxa each. Certain ethnobotanical features of the identified taxa, such as systematics, habitats, flowering times, local names and alternative uses in medicine were presented.

\footnotetext{
*Corresponding Author:

E-mail: hakgul@akdeniz.edu.tr
}

DOI: https://doi.org/10.24925/turjaf.v6i9.1191-1195.1994

\section{Introduction}

According to the World Health Organization (WHO) data, $80 \%$ of the population in developing countries supply their basic medical needs with traditional herbal medicines. At least $25 \%$ of pharmacological medicine are of vegetable origins (Selamoglu and Ozgen, 2016; Sevindik et al., 2017; Sevindik, 2018). Throughout history, individuals have utilized the plants in their natural environment for nutritional needs, as spices or medicines and improved their knowledge base on these resources. However, industrialization, destruction of the habitat, urban migration and cultural transformation affected the transfer of this knowledge negatively (Mulei et al., 2014; Pehlivan and Sevindik, 2018). In this context, determination of the regional use of the plants is significant in transferring ethnobotanical knowledge to new generations.

Duhok region, located on the north-western section in Iraq and includes large districts such as Zaho, Amidye, Akre, Semel, and Shikan, is a big province with 821 villages. The surface area is $9755 \mathrm{~km}^{2}$, and the population was 913.716 based on the 2004 census (Duhok University, 2018). General Duhok province map is presented in Figure 1 (Duhok Governorate, 2014).

Examination of the flora of Iraq demonstrated that there are 4000 plant species in 150 (141 flowering plants) genera. These plants $(25-3000 \mathrm{~m})$ grow in deserts, saline soils, and in northern mountains. Most plants indigenous to the Iraqi flora are also found in the flora of Turkey, Iran and Syria. About $20 \%$ of the plants in the region are similar to Mediterranean vegetation, while the number of trees is low (200 species), the number of herbaceous plants is high and most plants grow in the northern part of the region (Shahbaz 2010).

The present aimed to conduct an ethnobotanical analysis on the previously unexamined cultivated and gathered and naturally utilized plants in the Duhok (Iraq) region.

\section{Material and Method}

The indigenous plants that grow naturally in the province and its vicinity and used by the people for nutritional purposes, as spices or for medicinal purposes were investigated based on floristic and folkloric knowledge. For this purpose, a total of 183 individuals (114 females and 69 males) in different occupations were interviewed. The majority of interviewees were women occupied as plant pickers. Between 2011-2012, the markets in Duhok center and Zaho, Amidye, Akre, Şemel and Shikan districts were visited every week to collect these plants and information about these plants. The information on the location of the plant collection, the prevalence in the location of the plant collection, and purpose of sale were collected and the plants were collected from their natural habitat. Plants that are not indigenous to the region were excluded from the study. The collected plants were dried and transformed into herbarium specimens and identified. 
Flora of Iraq was used for description and distribution of the taxa identified in the study (Townsend and Guest (1966-1985)). Herbarium specimens of the collected plants were stored at Zaho University, Faculty of Arts and Sciences, Biology Department herbarium.

\section{Findings and Discussion}

The number and distribution of the interviewed individuals in the study are presented in Table 1. Furthermore, the plants collected in Duhok province and sold in the markets for nutritional and medicinal purposes and as spices are listed in Table $2 \mathrm{a}$ and $2 \mathrm{~b}$, and local uses for these plants are presented in Table 3.

Table 1 Gender distribution by research areas

\begin{tabular}{l|rrr}
\hline \multicolumn{1}{c}{ Research Areas } & Male & Female & Total \\
\hline Duhok Center & 17 & 15 & 32 \\
Zaho & 13 & 21 & 34 \\
Amidye & 12 & 26 & 38 \\
Akre & 7 & 18 & 25 \\
Semel & 9 & 19 & 28 \\
Shikan & 11 & 15 & 26 \\
Total & 69 & 114 & 183 \\
\hline
\end{tabular}

Table 2a Plants collected from Duhok and sold in markets

\begin{tabular}{|c|c|c|c|c|c|c|}
\hline \multirow{2}{*}{ Family } & \multirow{2}{*}{ Scientific Name } & \multirow{2}{*}{$\begin{array}{l}\text { Local } \\
\text { Name }\end{array}$} & \multirow{2}{*}{ Used Part } & \multirow{2}{*}{ M } & \multicolumn{2}{|c|}{ Gathering Place } \\
\hline & & & & & Coordinate & Date \\
\hline \multirow{2}{*}{ Alliaceae } & \multirow{2}{*}{ Allium sativum $\mathrm{L}$. } & \multirow{2}{*}{ Seer } & \multirow{2}{*}{ Stem, Leaf } & \multirow{2}{*}{1} & \multicolumn{2}{|c|}{ Duhok-Zakho-Sharansh } \\
\hline & & & & & $37^{\circ} 23^{\prime} 83^{\prime \prime N}-42^{\circ} 85^{\prime} 14^{\prime \prime} \mathrm{E}$ & 2013-04-20 \\
\hline \multirow{2}{*}{ Anacardiaceae } & \multirow{2}{*}{ Pistacia vera $\mathrm{L}$. } & \multirow{2}{*}{ Festaq } & \multirow{2}{*}{ Leaf, Gum } & \multirow{2}{*}{2} & \multicolumn{2}{|c|}{ Duhok-Bamerne } \\
\hline & & & & & $37^{\circ} 7^{\prime} 15^{\prime \prime N}-43^{\circ} 16^{\prime} 14^{\prime \prime E}$ & 2013-08-15 \\
\hline \multirow{2}{*}{ Anacardiaceae } & \multirow{2}{*}{ Pistacia terebinthus $\mathrm{L}$. } & & & & Duhok-Ban & \\
\hline & & Gezwan & Leat, Gum, Fruit & 2 & $37^{\circ} 7^{\prime} 15^{\prime \prime N}-43^{\circ} 16^{\prime} 14^{\prime \prime E}$ & 2013-08-15 \\
\hline & & & & & Duhok-Sarsenk-Ga & ountain \\
\hline Apiaceae & Anethum graveolens L. & Sebet & Fruit & 3 & $37^{\circ} 09^{\prime} 25^{\prime \prime} \mathrm{N}-43^{\circ} 48^{\prime} 72^{\prime \prime} \mathrm{E}$ & 2013-05-20 \\
\hline & & & & & Duhok-Se & \\
\hline Apraceae & Apıum graveolens $\mathrm{L}$. & Kerts & Root, Leat & 4 & $36^{\circ} 53^{\prime} 15^{\prime \prime} \mathrm{N}-43^{\circ} 00^{\prime} 34^{\prime \prime} \mathrm{E}$ & 2013-09-24 \\
\hline Aniaceae & Foeniculum vulgare & Rezvank & Ront Stem & 3 & Duhok-Qa & \\
\hline Apiaceac & Mill. & KeZyank & Root, Stem & 3 & $37^{\circ} 09^{\prime} 25^{\prime \prime} \mathrm{N}-43^{\circ} 48^{\prime} 72^{\prime \prime} \mathrm{E}$ & 2013-05-01 \\
\hline Asteraceae & Calendula officinalis $L$ & Gul Buhar & Leaf Flower Seed & 5 & Duhok-Zawit & \\
\hline Asteracead & 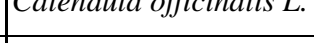 & Uur Dunar & & $J$ & $36^{\circ} 54^{\prime} 21^{\prime \prime N}-43^{\circ} 8^{\prime} 47^{\prime \prime E}$ & 2013-05-01 \\
\hline Asteraceae & Carduus marianus L & Kereng - & Fruit & 4 & Duhok-Ban & \\
\hline Asteraceae & fCarauns martanus L. & Kenger & Fruit & 4 & $37^{\circ} 7^{\prime} 15^{\prime \prime N}, 43^{\circ} 16^{\prime} 14^{\prime \prime} \mathrm{E}$ & 2013-04-15 \\
\hline Asteraceae & Matricaria chamomilla & & Flower & 3 & Duhok-Zawit & \\
\hline Asteraceae & L. & Baeben & Flower & 3 & $36^{\circ} 54^{\prime} 21^{\prime \prime N}-43^{\circ} 8^{\prime} 47^{\prime \prime E}$ & 2013-05-01 \\
\hline Brassicaceae & Brassica rapa subsp. & Selm & Root & 6 & Duhok-Se & \\
\hline Brassicacede & rapa $\mathrm{L}$. & Şemm & Koot & 0 & $36^{\circ} 54^{\prime} 21^{\prime \prime N}-43^{\circ} 8^{\prime} 47^{\prime \prime E}$ & 2013-09-24 \\
\hline Brassicaceae & Raphanus sativus L. & & Root & & Duhok-Se & \\
\hline Brassicaceae & Kapnanus sattvus L. & lever & Koot & 1 & $36^{\circ} 53^{\prime} 15^{\prime \prime} \mathrm{N}-43^{\circ} 00^{\prime} 34^{\prime \prime} \mathrm{E}$ & 2013-09-27 \\
\hline & & & & & Duhok-Ban & \\
\hline Capparaceae & Capparis spinosa L. & Kapar & Flower, Fruit, Root & 1 & $37^{\circ} 7^{\prime} 15^{\prime \prime N}-43^{\circ} 16^{\prime} 14^{\prime \prime} \mathrm{E}$ & 2013-06-15 \\
\hline Cucurbitaceae & Cucumis sativus L & Xevar & Eruit & 7 & Duhok-Se & \\
\hline cucurbitaceae & Cucumis satvus L. & xeyar & Fruit & 1 & $36^{\circ} 53^{\prime} 15^{\prime \prime} \mathrm{N}, 43^{\circ} 00^{\prime} 34^{\prime \prime} \mathrm{E}$ & 2013-06-15 \\
\hline & Citrullus lanatus & Zebes - & & & Duhok-Se & \\
\hline Cucurbitaceae & $\begin{array}{l}\text { (Thunb.) Matsum. \& } \\
\text { Nakai }\end{array}$ & Şety & Fruit, Seed & 8 & $36^{\circ} 53^{\prime} 15^{\prime \prime} \mathrm{N}-43^{\circ} 00^{\prime} 34^{\prime \prime} \mathrm{E}$ & 2013-09-15 \\
\hline Cucurbitaceae & Сucurbita peno L & Kolend & Eruit & 9 & Duhok-Se & \\
\hline & Сисuгbita реро L. & & Fruit & 9 & $36^{\circ} 53^{\prime} 15^{\prime \prime} \mathrm{N}-43^{\circ} 16^{\prime} 14^{\prime \prime} \mathrm{E}$ & 2013-06-24 \\
\hline Cupressaceae & Juniperus communis L. & Hevrest - & Fruit & 4 & Duhok-Za & \\
\hline & 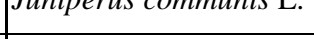 & & Fruil & 4 & $36^{\circ} 54^{\prime} 21^{\prime \prime N}-43^{\circ} 8^{\prime} 47^{\prime \prime E}$ & 2013-05-01 \\
\hline Fabaceae & Trigonella foenum- & Feonum - & Seed & 10 & Duhok-Qa & \\
\hline & graecum $\mathrm{L}$. & Helba & Necu & 10 & $36^{\circ} 86^{\prime} 67^{\prime \prime N}-43^{\circ} 00^{\prime} 00^{\prime \prime} \mathrm{E}$ & 2013-07-15 \\
\hline Fabaceae & Lens culinaris Medik. & Neesk & Seed & 11 & Duhok-Se & \\
\hline Fabaceae & Lens cuminarts Miedik. & Neesk & Seed & 11 & $36^{\circ} 53^{\prime} 15^{\prime \prime N}-43^{\circ} 00^{\prime} 34^{\prime \prime E}$ & 2013-05-05 \\
\hline Fabaceae & Glycurrhiza olabra L & Reha suse & Root & 12 & Duhok-Ma & \\
\hline rabaceae & Glycyrrhiza glabra L. & Rena suse & Root & 12 & $37^{\circ} 06^{\prime} 39^{\prime \prime} \mathrm{N}-43^{\circ} 09^{\prime} 65^{\prime \prime} \mathrm{E}$ & 2013-08-15 \\
\hline Juglandaceae & Juglans regia $\mathrm{L}$. & Geez & Leaf, Fruit, Stem, & 13 & Duhok-Sarsenk-Ga & ountain \\
\hline Jugrandacéae & Jugians regia $\mathrm{L}$. & Geet & Seed & 15 & $37^{\circ} 09^{\prime} 25^{\prime \prime} \mathrm{N}-43^{\circ} 48^{\prime} 72^{\prime \prime} \mathrm{E}$ & 2013-05-01 \\
\hline J amiaceae & I cimum hasilicum I & Gul Rehan & Leaf & & Duhok-Se & \\
\hline Lamiaceae & Ucıтит basilıcum L. & Gul Renan & Leat & 14 & $36^{\circ} 53^{\prime} 15^{\prime \prime} \mathrm{N}-43^{\circ} 00^{\prime} 34^{\prime \prime} \mathrm{E}$ & 2013-05-01 \\
\hline & Rosmarinus officinalis & & & & Duhok-Se & \\
\hline Lamiaceae & & Jaterk & Leat, Flower & 15 & $36^{\circ} 53^{\prime} 15^{\prime \prime} \mathrm{N}-43^{\circ} 00^{\prime} 34^{\prime \prime} \mathrm{E}$ & 2013-06-24 \\
\hline Lamiaceae & Mentha piperita $\mathrm{L}$. & Peeng & Leaf & 16 & Duhok-Qa & \\
\hline & & & & 10 & $36^{\circ} 86^{\prime} 67^{\prime \prime N}-43^{\circ} 00^{\prime} 00^{\prime \prime} \mathrm{E}$ & 2013-06-15 \\
\hline Lamiaceae & Hyssopus officinalis L. & Qesel & Stem Leaf & 4 & Duhok-Zawit & \\
\hline & 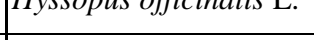 & mehmeed & & 4 & $36^{\circ} 54^{\prime} 21^{\prime \prime N}, 43^{\circ} 8^{\prime} 47^{\prime \prime E}$ & 2013-05-01 \\
\hline Lythraceae & Punica granatum $\mathrm{L}$. & Henar & Root. Fruit & 13 & Duhok-Zakho- & shte \\
\hline & & & & & $37^{\circ} 15^{\prime} 00^{\prime \prime} \mathrm{N}, 42^{\circ} 68^{\prime} 33^{\prime \prime} \mathrm{E}$ & 2013-09-05 \\
\hline
\end{tabular}


Table 2b Plants collected from Duhok and sold in markets

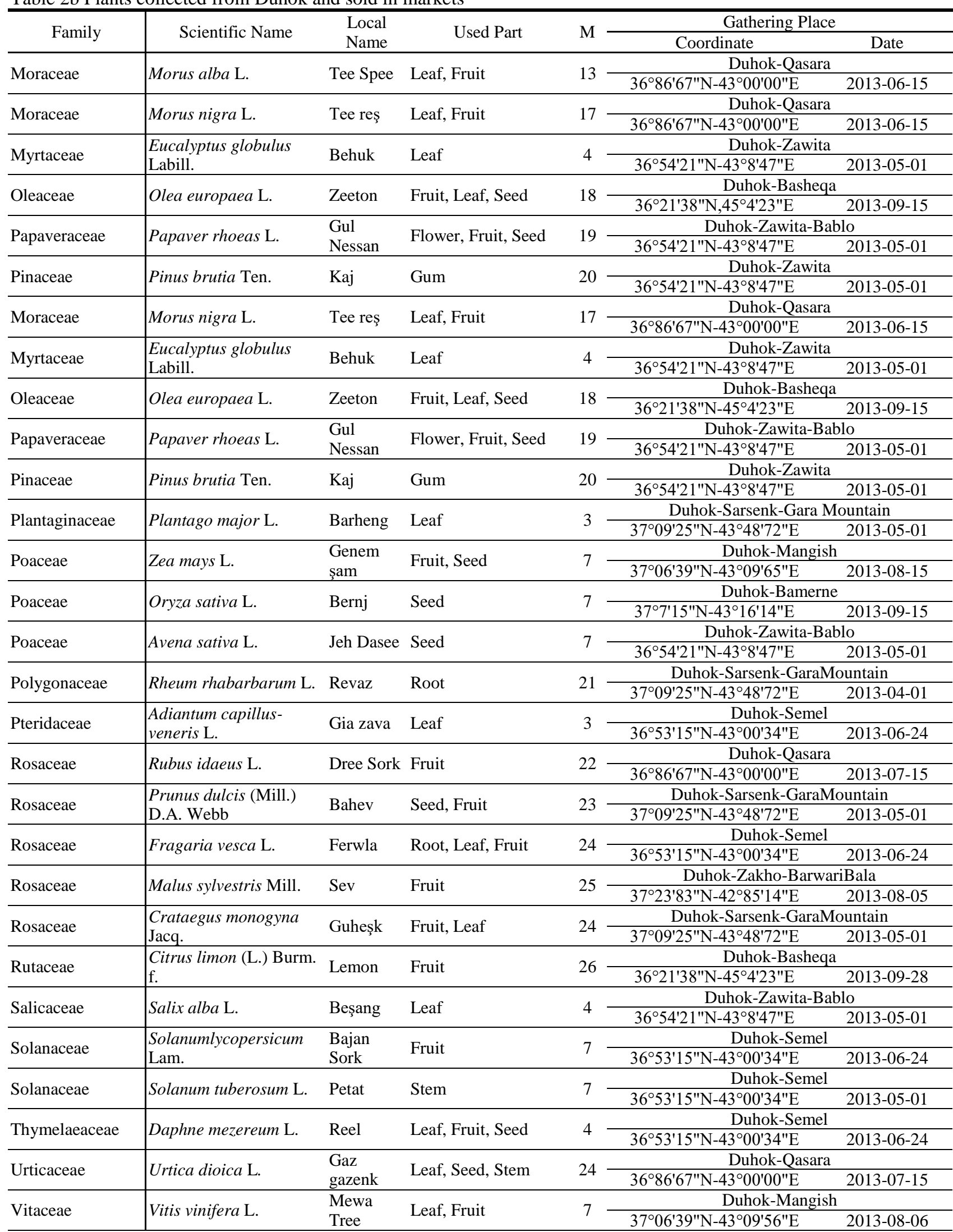

M: Intended Use and Method, 1: Medicinal Drug (Internally), Food (Internally and Spice), 2: Medicinal Drug (Decoction, Internally), 3: Medicinal Drug (Infusion), 4: Medicinal Drug (Decoction), 5: Medicinal Drug (Internally), 6: Medicinal Drug (Water), Food (Internally), 7: Food (Internally), 8: Medicinal Drug and Food (Internally), 9: Medicinal Drug and Food (Externally and Internally), 10: Medicinal Drug (Externally), 11: Food (Soup), 12: Medicinal Drug (Syrup and Decoction), 13: Medicinal Drug (Decoction), Food (Internally), 14: Medicinal Drug (Decoction Mouthwash),

15: Medicinal Drug (Infusion, Externally), 16: Medicinal Drug (Infusion), Food (Spice), 17: Medicinal Drug (Decoction and Jam), Food (Internally), 18: Medicinal Drug (infusion and oil), Food (Internally), 19: Medicinal Drug (Syrup and Internally), 20: Medicinal Drug (Externally and Internally), 21: Medicinal Drug (Syrup), 22: Food (Jam), 23: Cosmetic (Externally), Food (Internally), 24: Medicinal Drug (Infusion), Food (Internally),

25: Medicinal Drug (Infusion, Food (Internally), 26: Medicinal Drug (Infusion), Food (Water and Internally) 
Table 3 Local use of plants

\begin{tabular}{|c|c|}
\hline Scientific Name & Local Use \\
\hline A. sativum & Stem and leaves are used as appetizer and germicide. It is also used as a spice. \\
\hline $\begin{array}{l}P . \text { vera and } P \text {. } \\
\text { terebinthus }\end{array}$ & $\begin{array}{l}\text { After the leaves are boiled, they are placed on the chest and used in bronchitis treatment. It is also used in } \\
\text { the morning to drink stomach ache by drinking on an empty stomach. Gum is used for stomach discomfort. }\end{array}$ \\
\hline Anethum graveolens & The fruit is used as an infusion, sedative and digestive. \\
\hline Apium graveolens & The roots and leaves are boiled, used in abdominal bloating, constipation and urinary excretion. \\
\hline F. vulgare & Root and trunk parts are used in the treatment of low back pain and liver in the form of infusion. \\
\hline C. officinalis & Leaves, flowers and seeds are used for indigestion and stomach ailments. \\
\hline C. marianus & Decoction prepared from fruit is used for liver poisoning and gallstones removal. \\
\hline M. chamomilla & The flowers are used as infusion, sedative, and getter. \\
\hline B. rapa subsp. rapa & The juices of root parts are used for appetite, stomach and liver disorders. It is also consumed as food. \\
\hline R. sativus & Root parts are used as diuretic, constipation reliever and appetite opener. It is also consumed as food. \\
\hline C. spinosa & $\begin{array}{l}\text { It is used as a diuretic, an antiseptic and a force exerting a flower, fruit and root bark. Leaves are used for } \\
\text { salad. Fruits are used as aphrodisiacs by being made directly or by pickling and defeating. }\end{array}$ \\
\hline C. sativus & Fruit is consumed as food. \\
\hline C. lanatus & Fruit is consumed as food, while the kernel is consumed against intestinal parasites. \\
\hline C. реро & Fruit is consumed in eczema treatment and as food. \\
\hline J. communis & Fruits are used for medicinal purposes in colds. \\
\hline T. foenum-graecum & Seeds are dried and crushed to powder and used for wound healing. \\
\hline L. culinaris & Seeds are used as food by making soup. \\
\hline G. glabra & $\begin{array}{l}\text { Syrup prepared from roots is used in the treatment of bronchitis, asthma and cough. Root decoction is used } \\
\text { for stomach pain, abdominal pain and intestinal disorders. }\end{array}$ \\
\hline J. regia & $\begin{array}{l}\text { The decoy prepared from the fruit is used as a cholesterol regulator and against atherosclerosis. Decoction, } \\
\text { prepared from body shells, is used as a blood sugar lowering agent. After the decongestion of young shoots } \\
\text { is absorbed into a cloth, the cloth is wrapped around the painful area and used to relieve rheumatic pain. } \\
\text { After the fruit shells are dried and powdered, they are mixed with henna and used in skin diseases. Seeds are } \\
\text { used as food. }\end{array}$ \\
\hline O. basilicum & Leaves are used as gargle by boiling in mouth and throat inflammation. \\
\hline R. officinalis & $\begin{array}{l}\text { The tea of the flowers is used as vitality and strength in the body. Leaves are used externally as simple } \\
\text { healing remedies. }\end{array}$ \\
\hline M. piperita & Leaf tea is used in colds and influenza-like illnesses. It is also used as a spice. \\
\hline H. officinalis & Decoction prepared from the body and leaves is used against extender and perspiration. \\
\hline P. granatum & Decoction of roots is used against diarrhea. Fruits are consumed as food. \\
\hline M. alba & s used as an antipyretic and diuretic. Fruits are consumed as food. \\
\hline M. nigra & $\begin{array}{l}\text { Decoction prepared from leaves, in the morning on an empty stomach to drink a cupful of blood sugar is } \\
\text { used to reduce. It is used against anemia by making a jam. }\end{array}$ \\
\hline E. globulus & Decoction, prepared from leaves, is used in asthma, cold and cough. \\
\hline O. europaea & $\begin{array}{l}\text { Leaves are used as cholesterol regulator in tea form. Fruity rubella is used in the treatment of rheumatism, } \\
\text { eye diseases and liver diseases. Fruit is used as an analgesic, seeds against rheumatism. It is also consumed } \\
\text { as food. }\end{array}$ \\
\hline P. rhoeas & $\begin{array}{l}\text { Flower parts are made by syrup, cough cutter and breast softener, cold and bronchitis. Fruit and seeds are } \\
\text { used as painkillers and tranquilizers. }\end{array}$ \\
\hline P. brutia & $\begin{array}{l}\text { Pine Gum is used as a germicide in the microbial diseases of respiratory and urinary tracts. It is used } \\
\text { externally for wound care by bringing cream into shape. }\end{array}$ \\
\hline P. majör & Leaves are made of tea and used as wound healing, diuretic, phlegm removal. \\
\hline Z. mays & Fruits and seeds are used as food. \\
\hline O. sativa & Seeds are used as food. \\
\hline A. sativa & Seeds are used as food. \\
\hline R. rhabarbarum & $\begin{array}{l}\text { Root parts are used for stomach and intestinal disorders by making syrup. In addition, the use of the laxative } \\
\text { effects, though rare, are also available. }\end{array}$ \\
\hline A. capillus-veneris & Leaves are made of tea and used as expectorant and cough cutter. \\
\hline R. idaeus & Fruits are consumed as food by making jam. \\
\hline P. dulcis & The seeds are used for exfoliating skin by extracting oil and the seeds and fruits are consumed as food. \\
\hline F. vesca & Roots and leaves are consumed as tea as appetizing, constipating and diuretic, as fruit food. \\
\hline M. sylvestris & Fruit is consumed as tea and food. \\
\hline C. monogyna & Leaves are made of tea, heart disease and blood pressure lowering is consumed. Fruits are used as food. \\
\hline C. limon & $\begin{array}{l}\text { The fruit is consumed directly as a food in the form of tea by squeezing the water. Tea is used for infections } \\
\text { of the intestine. }\end{array}$ \\
\hline S. alba & $\begin{array}{l}\text { Decoction prepared from the leaves in the treatment of rheumatism, kidney is used to lower the sand and to } \\
\text { lower blood sugar. }\end{array}$ \\
\hline S. lycopersicum & Fruit is consumed as food. \\
\hline S. tuberosum & Stem is consumed as food. \\
\hline D. mezereum & The mixture of leaves, fruits and seeds is used as a decoction and laxative. \\
\hline U. dioica & $\begin{array}{l}\text { It is used to make tea leaves of the leaves and body, to excrete the diuretic, the kidneys. Seeds are used to } \\
\text { strengthen the immune system. It is also consumed as food. }\end{array}$ \\
\hline V. vinifera & Leaves and fruit are consumed as food. \\
\hline
\end{tabular}




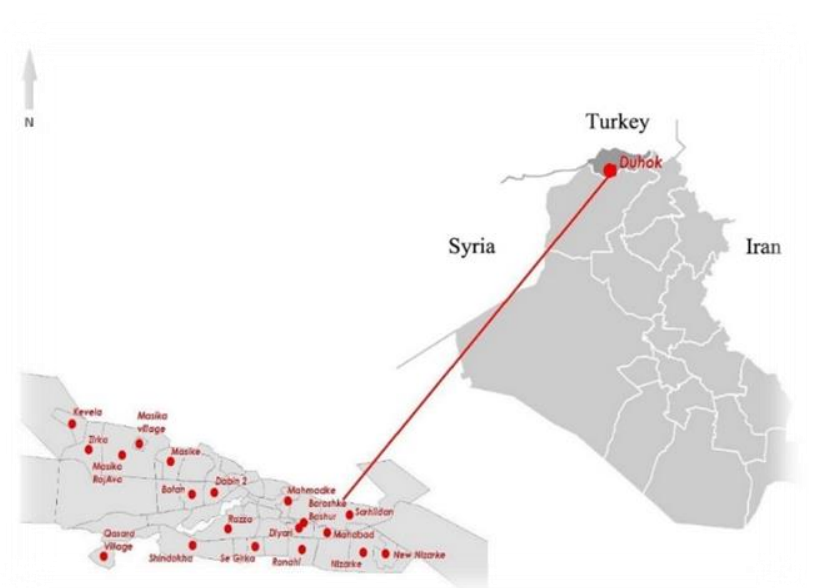

Figure 1 General View of Duhok Province

Table 4 Proportional Distribution of Families in Research

\begin{tabular}{l|cc}
\hline \multicolumn{1}{c|}{ Family } & $\begin{array}{c}\text { Number of } \\
\text { Taxon }\end{array}$ & $\begin{array}{c}\text { Percentage } \\
(\%)\end{array}$ \\
\hline Anacardiaceae & 2 & 4.08 \\
Apiaceae & 3 & 6.12 \\
Asteraceae & 3 & 6.12 \\
Brassicaceae & 2 & 4.08 \\
Cucurbitaceae & 3 & 6.12 \\
Fabaceae & 3 & 6.12 \\
Lamiaceae & 4 & 8.16 \\
Moraceae & 2 & 4.08 \\
Poaceae & 3 & 6.12 \\
Rosaceae & 5 & 10.20 \\
Solanaceae & 2 & 4.08 \\
Others & 17 & 34.72 \\
\hline
\end{tabular}

Distribution of the taxa identified in the study area by family is presented in Table 4. The highest prevalence was observed in the Rosaceae family with 5 taxa, followed by Fabaceae and Lamiaceae family with 4 taxa, Apiaceae, Asteraceae, Cucurbitaceae, Poaceae family with 3 taxa, and Anacardiaceae, Brassicaceae, Moraceae and Solanaceae family with 2 taxa.

The intended use of 82 plants were reported in ethnobotanical study conducted in Erbil (Iraq), where 18 herbalists were interviewed (Mati and de Boer 2010). When compared to this study, 49 taxa indigenous to Duhok province were identified and their intended use and related methods were determined in the present study.

\section{Conclusion}

Analysis of the plant samples collected and sold at markets in Dohok province revealed 46 species and 49 taxa in 28 genera. It was determined that various parts of the plants identified in Duhok province were generally used in decoction form as folk medicine. In conclusion, the ethnobotanical information on Duhok region was determined for the first time in the present study, which was a significant contribution to the literature.

\section{References}

Duhok Governorate. 2014. IDP (Iraq Duhok Provience) Factsheet. Reach an initiative of impact initiatives ACTED and UNUSAT.

Duhok University. 2018. http://web.uod.ac/about/duhok-city/ Date of access: 30-04-2018

Mati E, de Boer H. 2010. Ethnobotany and Trade of Medicinal Plants in the Qaysari Market, Erbil, Kurdish Autonomous Region. Department of Systematic Biology. Uppsala University. Sweden.

Mulei MJ, Otieno FD, Onkware OA. 2014. An Ethnobotanical Study of Swamp Wetland Vegetation in Uasin Gishu County, Kenya: Ethnobotany Research and Applications, 12(1): 315-324

Pehlivan M, Sevindik M. 2018. Antioxidant and Antimicrobial Activities of Salvia multicaulis. Turkish Journal of Agriculture - Food Science and Technology, 6(5): 628-631, 2018

Selamoglu Z, Ozgen S. 2016. Therapeutic Potential of Saffron Crocus (Crocus sativus L.). Turkish Journal of AgricultureFood Science and Technology 4(12): 1240-1245.

Sevindik M, Akgul H, Pehlivan M, Selamoglu Z. 2017. Determination of therapeutic potential of Mentha longifolia ssp. longifolia. Fresen Environ Bull 26: 4757-4763.

Sevindik M. 2018. Pharmacological Properties of Mentha Species. J Tradit Med Clin Natur, 7(259): 2.

Shahbaz SE. 2010. A Field Guide To The Trees And Shrubs Of Kurdistan Region Of Iraq. University of Dohuk.

Townsend CC, Guest E. 1966-1985. Flora of Iraq, Volumes 1-4, 8-9. Ministry of Agriculture and Agrarian Reform and Bentham-Moxon Trust. Baghdad, Iraq. 